\title{
Land-Use Change Trends in the Interior Lowland Ecoregion
}

Scientific Investigations Report 2007-5145

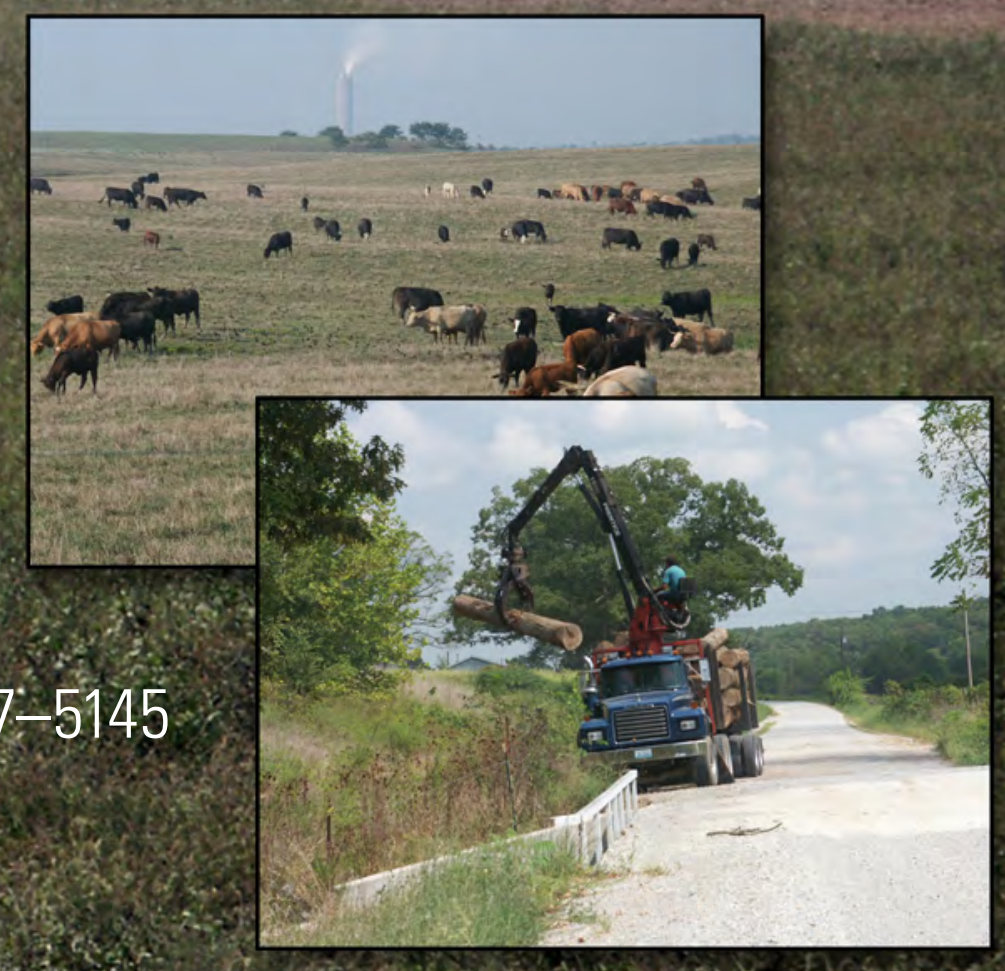


Cover Photographs. Tractor discing field in Southern Illinois (cover). Cattle grazing on reclaimed land of a coal mine in Kentucky (top inset). Truck loading logs in Southern Illinois (bottom inset). Photographs by Thomas R. Loveland, U.S. Geological Survey, 2003. 


\section{Land-Use Change Trends in the Interior River Lowland Ecoregion}

By Dalia E. Varanka and David K. Shaver

Scientific Investigations Report 2007-5145 


\section{U.S. Department of the Interior DIRK KEMPTHORNE, Secretary}

\section{U.S. Geological Survey \\ Mark D. Myers, Director}

\section{U.S. Geological Survey, Reston, Virginia: 2007}

For product and ordering information:

World Wide Web: http://www.usgs.gov/pubprod

Telephone: 1-888-ASK-USGS

For more information on the USGS--the Federal source for science about the Earth, its natural and living resources, natural hazards, and the environment:

World Wide Web: http://www.usgs.gov

Telephone: 1-888-ASK-USGS

Any use of trade, product, or firm names is for descriptive purposes only and does not imply endorsement by the U.S. Government.

Although this report is in the public domain, permission must be secured from the individual copyright owners to reproduce any copyrighted materials contained within this report.

Suggested citation:

Varanka, D.E., and Shaver, D.K., 2007, Land-use change trends in the Interior River Lowland ecoregion: U.S. Geological Survey Scientific Investigations Report 2007-5145, 12 p. 


\section{Contents}

Abstract
Introduction.
The Physical and Historical Setting
Resproach and Methods
Discussion

\section{Figures}

\section{1-2. Maps showing-}

1. Interior River Lowland ecoregion with study area sample blocks.

.2

2. Ecoregion and University of Illinois at Urbana-Champaign agricultural area borders in Illinois.

\section{Tables}

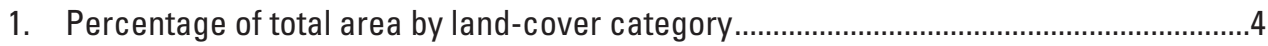

2. Rates of land-cover change by percent .......................................................................

3. Gross change in regional area of the most common land-use conversions in the Interior River Lowland ecoregion by percent, in intervals from 1973-2000 .................5

4. Cumulative change in percent of regional area between land-use sectors

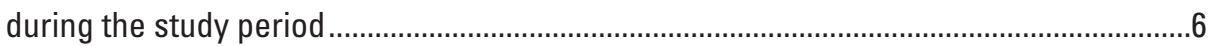

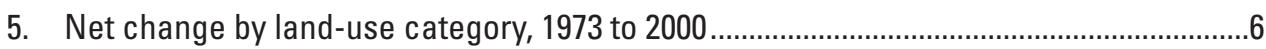

6. Trends in St. Louis statistical metropolitan area total population change..........................9

7. Land-use change trends findings from comparative studies by land-use

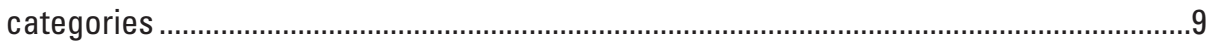

8. Change in land-use categories by percent between comparative studies, 1980 to 2000 


\section{Conversion Factors}

\begin{tabular}{lcl}
\hline \multicolumn{1}{c}{ Multiply } & By & \multicolumn{1}{c}{ To obtain } \\
\hline acre & Area & \\
acre & 4,047 & square meter $\left(\mathrm{m}^{2}\right)$ \\
acre & 0.4047 & hectare $($ ha) \\
acre & 0.4047 & square hectometer $\left(\mathrm{hm}^{2}\right)$ \\
square mile $\left(\mathrm{mi}^{2}\right)$ & 0.004047 & square kilometer $\left(\mathrm{km}^{2}\right)$ \\
square meter $\left(\mathrm{m}^{2}\right)$ & 2.59 & square kilometer $\left(\mathrm{km}^{2}\right)$ \\
hectare $($ ha) & 0.0002471 & acre \\
square hectometer $\left(\mathrm{hm}^{2}\right)$ & 2.471 & acre \\
square kilometer $\left(\mathrm{km}^{2}\right)$ & 2.471 & acre \\
square kilometer $\left(\mathrm{km}^{2}\right)$ & 247.1 & acre \\
\hline
\end{tabular}




\title{
Land Use Change Trends in the Interior River Lowland Ecoregion
}

\author{
By Dalia E. Varanka and David K. Shaver
}

\section{Abstract}

This report describes land-cover trends in the Interior River Lowland ecoregion, located primarily in southern Illinois and includes the confluence areas of the Mississippi, Missouri, Ohio, Illinois, and Wabash Rivers, and their tributaries. Land-cover change statistics were tabulated from forty 10 kilometers $(\mathrm{km})$ by $10-\mathrm{km}$ multi-spectral remote-sensing sample areas collected from 1973 to 2000 and classified into nine primary land-cover categories. The results indicated stable land use. Agricultural land use increased, but acreage was lost to urbanization, especially in the St. Louis area. Recreational and conservation land uses are underrepresented relative to population demand. Findings were comparable to results of other land use research.

\section{Introduction}

Environmental conditions and quality may be attributable to the impacts of human-induced land-use change and the environmental response to those changes. Examples of critical environmental services that are impacted by land use include climate, water quality, and human health. Land use also is an indicator of social and economic conditions. The purpose of land-use management is to foster productivity, and thereby benefit from land resources for a better quality of life; therefore, stakeholders with competing interests in land use are concerned with broader geographical and temporal trends.

This report examines these trends in a key sub-region of the U.S. Midwest by presenting an analysis of the types and rates of land-use/land-cover change within the Interior River Lowland ecoregion (Omernik, 1987). Land-use demands for the resources of this region are significant and varied from different social and physical science perspectives. The region is a contributor to the Grain Belt, and, therefore, a contributor in the regional, national, and international agricultural economies. The region is vulnerable to the suburban and exurban growth associated with St. Louis and other statistical metropolitan areas. The prominent waterway connections of the ecoregion provide access across the continent in several directions. The demonstrated coal reserve base is the second largest in the United States, is the largest in the nation for bituminous coal, and provides a key component of national energy resources. Expanding populations require increases in forest and wetlands for conservation and recreation, but the increases have not competed well with land use that has been driven by stronger economic interests.

The hypothesis, based on findings and conditions described by previous reports was that the regional land use is stable, though change may result from social, environmental, and economic challenges in the future (Iverson, 1988; Schneider and Fettig, 1979; Lant and others, 2001; Duram and others, 2004). This paper gives a baseline description of the environmental context of the ecoregion, a discussion of specific analytical findings, and compares the study findings to the results of two other studies. Social, economic, and environmental implications of the study results that could form the basis of future research are discussed.

\section{The Physical and Historical Setting}

The Interior River Lowland ecoregion is "made up of many wide, flat-bottomed terraced valleys, forested valley slopes, and dissected glacial till plains" (Omernik, 2006). The ecoregion is formed primarily by the confluences of the Mississippi, Missouri, Ohio, Illinois, and Wabash Rivers, and numerous tributaries flowing from the broad flatlands of Illinois and Indiana south toward the Illinois basin (fig. 1). The Cumberland and Tennessee Rivers enter the Ohio River from the south in this region. The region is composed primarily of interstitial lands between the rivers, the largest of which is all of southern Illinois. The ecoregion also includes western parts of Illinois (between the Illinois and Mississippi Rivers) and Indiana, and smaller areas around St. Louis, Missouri, and in northwestern Kentucky - all of which join the major rivers and have tributaries that have dissected the adjacent uplands. The region is bounded by the river bluffs of the Mississippi River and the Ozarks border to the west, and the Shawnee Hills of southern Illinois, which separates it from the river valleys to the south. The U.S. Geological Survey (USGS) Land Cover Trends project followed the Level III Ecoregion delineations of the Continental United States, revised March 1999. More recently, the southern boundary of the Interior River Lowland 


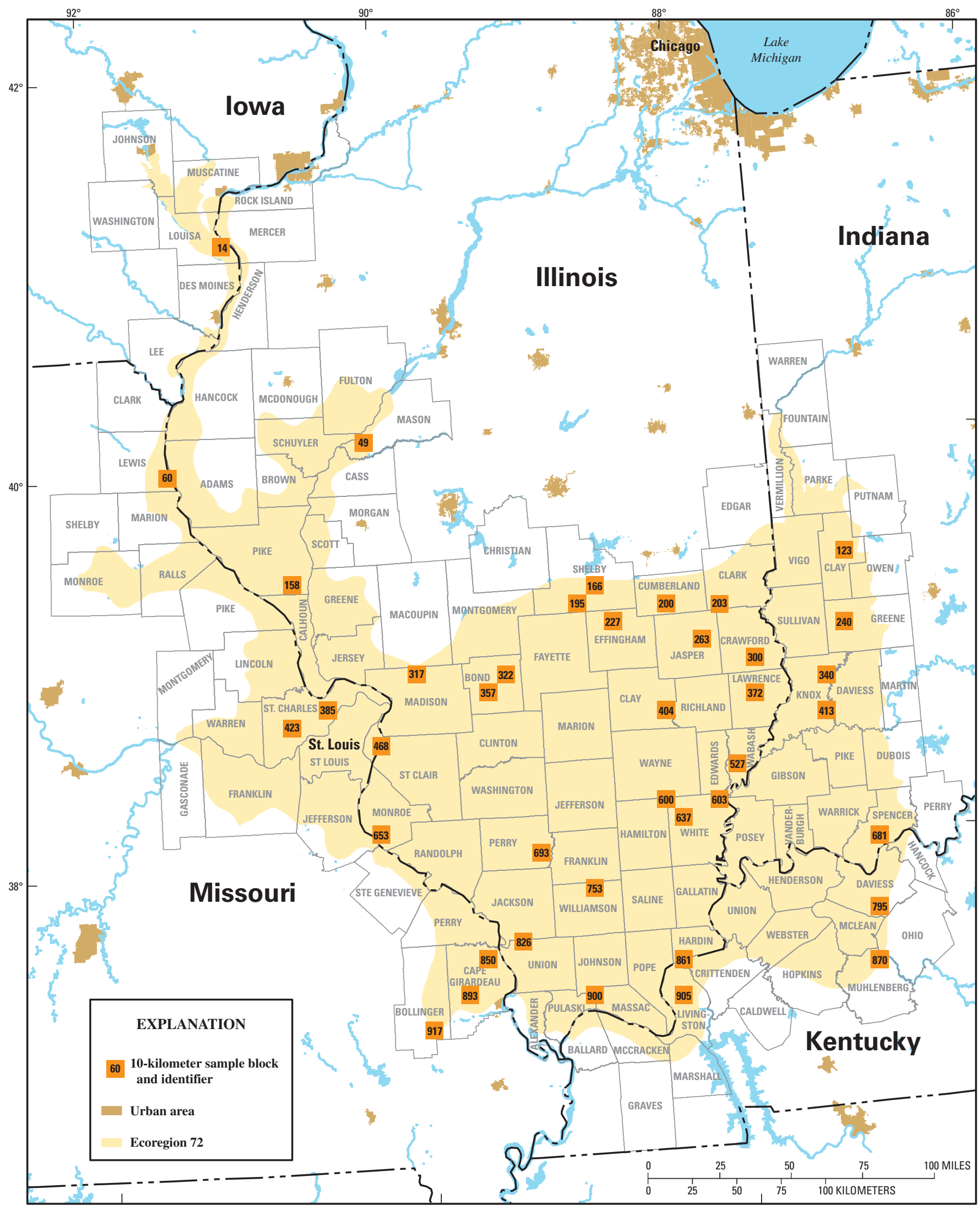

Environmental Systems Research Institute, Inc. (ESRI) Data and Maps, 2006

Figure 1. Interior River Lowland ecoregion with study area sample blocks. 
ecoregion was revised to exclude the Shawnee Hills of Illinois. The eastern boundary is an undelimited dissected plateau of the Interior Low Plateaus (Fenneman, 1946). The overall area of the ecoregion is approximately 373,000 square kilometers. Omernik (1995, p. 49) defined ecoregions based on some consistency of landforms, responses to land use, soils, and potential natural vegetation. The topography of the region varies between major flood plains, which include leveling by the major cities and cutting by rivers, and upland areas of drier, flatter valleys of smaller streams and rivers. Away from the rivers, southern Illinois is composed of level till plains produced by Illinoisan glaciations over lowland of typically Paleozoic sedimentary rock. These lowlands range from 90 to 150 meters in elevation, but the southern and northwestern edges of the region have hilly elevations reaching about 300 meters.

In addition to the landforms, climate is an important determinant of soil and vegetative cover. The climate has a history of erratic precipitation and temperatures, perhaps because of the regional location between the humid eastern United States and the continental character of the Plains (Changnon and others, 2004). The southern part of the region is characterized by hot, humid summers, though some drought often is experienced in July and August. The native vegetation of this area was prairie grasses on the level lands and broad-leaf deciduous trees on the slopes (Duram and others, 2004). The prairie is almost entirely gone, but soil and climate conditions support corn and grain agriculture instead.

The historical legacy of the region indicates that agriculture would continue in lowlands and decline in hilly areas, but the increase of agricultural land use varied with land characteristics, specifically as a result of soil conditions, diverse settlement patterns, and the changing technology of agricultural practice (Christensen and Harper, 1967). Alluvial soils in the lowland vary widely in their qualities, but their depth and flat surface lend them well to agriculture, if other concerns can be managed. Highlands are only marginally appropriate for farming. The thin and leached soils in the Kentucky part of the region are poor for crop agriculture. Loess deposits in the southwestern part of the region are good for farming, but vulnerable to erosion. Through the center of the region, clay pans form from fine particles sifting downward from the flat, level land to the substrata. The original tall-grass prairie cover was able to penetrate these clay pans, keeping the ground porous for soil development, but after the introduction of annual crops whose roots were much more shallow, these hard soil layers held water near the surface and restricted ground-water recharge and root penetration. Crop farming was restricted in this way until the technology was developed to break up these clay pans (Kircher, 1967).

Typical land-use/land-cover classes in this region were in five predominant groups: farm woodland, grass/pasture, and crop; non-farm woodland and grass for recreation and wildlife; strip mines; urban and extended transportation; and water and wetland. Agriculture and mining historically have been the important economic drivers of smaller settlements and cities in the region. Agriculture is more productive in the Illinois counties of the study area, whereas raising livestock is dominant in Missouri and other sub-regions with lower-quality soils. Part-time farms operated by families with other employment are more common. Coal mining, an important industry throughout the first one-half of the 20th century, is centered in southern Illinois and western Kentucky, and along the Illinois basin toward the northwestern part of Illinois (Jacobson and Korose, 2003). The subsurface coal reserves are mined by strip and shaft methods, which leave surface wastes. The region also is mined for other minerals and metal ores.

The St. Louis metropolitan area grew to be the primary urban area of this region, encompassing seven counties across the Mississippi River in Missouri and Illinois. The development and expansion of the city was shaped by transportation. Beginning with ferries and steamboats from about 1820 to just before the Civil War, steamboat travel prevailed up and down the main rivers. Railroads dominated around the turn of the $20^{\text {th }}$ century; ship-rail-motor-truck transportation networks began in about 1920. Just before the study period of land-use change, St. Louis was the second largest rail center in the country and ranked as the second largest trucking center in the U.S. (St. Louis City Plan Commission, 1969). In addition, shipping continued on the outstanding river network system. Lambert International airport began operating passenger and freight service in 1928. The St. Louis Regional Chamber and Growth Association slogan "Perfectly Centered, Remarkably Connected" suggests that location and position on national networks contributed to the economical advantage of the St. Louis region.

The economy of St. Louis became diverse, with no one industry having a large share of the total activity. Plentiful coal and water meet the needs for industry energy and processing, in East St. Louis, Illinois. St. Louis, Missouri, had almost all the manufacturing output and labor in the vicinity. Outside St. Louis, the rural nature of the Interior River Lowland ecoregion supported a pattern of urbanization in southern Illinois called "dispersed cities" (Christensen and Harper, 1967, p. 32). The dispersed city pattern in southern Illinois consists of a dozen or so smaller centers of urbanization that remain after the decline of an economic and employment activity, such as mining or railroad. Together the dispersed city forms an area of a couple of thousand people, but lacks the amenities of medium or large cities, instead, a duplication of low-level urban services results in multiple places. This pattern illustrates the urbanizing effects-large plants locate outside city limits, so they pay few taxes; new plants are automated, so they employ few people and require a different skill set, so employees are hired from outside the area. These networks moved materials to and across the region for development and trade, but most of the traffic generated on these routes was through-traffic, and had mild effects on the region. Petroleum products are shipped from the Gulf Coast to industries on the rivers that ship minerals, metals, and chemicals. Grain is shipped on the rivers and then internationally. Cities that centered on river transportation are now much less affected by its traffic because the bulk of 
transport materials are shipped to distribution terminals and industrial sites outside the cities.

Landscape attributes, perhaps soil types particularly, led to a strong association with agriculture in southern Illinois. The Interior River Lowland ecoregion offered strong support for intensive land-use types such as urbanization and water cover. At the beginning of this study, the Interior River Lowland ecoregion had a stable economy and was poised to develop new economic sectors, such as recreation and higher education, and to capitalize on the efficient use of legacy land uses such as agriculture and mining.

\section{Approach and Methods}

The objectives of this study are to identify types and rates of land use/land-cover changes in the late 20th century by an ecoregion. Remote sensing analysts classified 40 randomly selected sample areas of 10 kilometer x 10 kilometer from the Landsat Thematic Mapper archives data (1973, 1980, 1986, 1992, and 2000) for the study (Loveland and others, 2002). Land use/land-cover data were categorized according to nine themes: water, developed, mechanically disturbed, mining, naturally bare land, forest, grass/shrub, agriculture, and wetland. The results of the land change interpretations have a margin of error of $+/-1$ percent at a confidence level of 85 percent (Griffith and others, 2003; Stehman and others, 2003). Field crews collected data from field visits. This method contrasts with most land surveys based on census and mapping approaches and tests a cost-efficient approach to landscape monitoring. The advantages and disadvantages are discussed in other studies (Riitters and others, 2006).

\section{Results: Land-Use Change from 1973 to 2000}

The results of the investigation indicated that cropland use is intense, and urbanization is expanding, based on several economic sectors and industries. Coal mining and land reclamation are active, though fluctuating. Though historically rich in natural resources, natural wood and wetland resources of the ecoregion are limited. Some land was converted to water, for example, as new lakes associated with subdivisions (Darrell Napton, U.S. Geological Survey, written commun., 2003). The study determined that levels of change during the study period in all land-use categories of the region never exceeded a normalized average rate of 0.26 percent per year. Land-use sectors with the greatest loss during the entire study period were forest land, losing 0.65 percent, and agricultural land, losing 0.52 percent of total regional area. The most prevalent conversions were forest to agricultural land ( 0.57 percent $)$ and agriculture to developed land ( 0.32 percent). The results indicate agricultural production intensification despite land-area losses and development in the region. Other land-use levels, such as mining and wetlands, vary.

After classifying the sample data and analyzing the change in data between different dates, the following statistics resulted. In the Interior River Lowland ecoregion, the levels of land-use categories as percent of total area from 1973 to 2000 remained relatively stable (table 1 ). The percentages of total land area devoted to primary land-use categories averaged approximately 64.7 percent agriculture, 21.3 percent forest, 6.1 percent developed, 2.71 percent water, and 4.5 percent wetlands (the remaining 0.69 percent of land area was attributed to mining, mechanically disturbed land, natural bare land, and grass/shrub land). All stayed relatively constant during the study period.

The rate of change, when normalized from time intervals of 6, 7, or 8 years to an average annual value for the 27 -year period, decreased from 0.26 percent from 1973 to 1980 to 0.20 percent by 1992, but rose slightly, by 0.01 percent, from 1992 to 2000 (table 2). The land uses of the study area are stable, though variable within short periods of time; thus, two types of change were measured. Gross change was measured for time intervals time from 1973 to 2000, and net change in area was measured between beginning and ending dates of the study period. The net change in area by land uses greater than 1 percent of the total region were agriculture, 0.66 percent increase; forest, 2.27 percent decline; developed, 1.61 percent increase; and water, 0.16 percent increase (table 1 ). The percentage of total area in wetlands stayed the same.

Forest to agricultural land conversions (0.67 percent) were the most dominant trend through 1992 (table 3). Other

Table 1. Percentage of total area by land-cover category.

\begin{tabular}{cccccccccc}
\hline Year & Water & Developed & $\begin{array}{c}\text { Mechanically } \\
\text { disturbed }\end{array}$ & Mining & Natural bare & Forest & $\begin{array}{c}\text { Grass/ } \\
\text { shrub land }\end{array}$ & Agriculture & Wetland \\
\hline 1973 & 2.64 & 5.37 & 0.11 & 0.13 & 0.02 & 22.69 & 0.5 & 63.99 & 4.55 \\
1980 & 2.70 & 5.79 & .09 & .10 & .02 & 21.77 & .44 & 64.55 & 4.54 \\
1986 & 2.70 & 5.98 & .03 & .14 & .02 & 21.15 & .42 & 65.04 & 4.51 \\
1992 & 2.75 & 6.24 & .02 & .24 & .02 & 20.68 & .45 & 65.10 & 4.52 \\
2000 & 2.80 & 6.98 & .02 & .11 & .02 & 20.42 & .44 & 64.65 & 4.56 \\
\hline
\end{tabular}


Table 2. Rates of land-cover change by percent.

[Interval rate of change normalized to annual value]

\begin{tabular}{ccc}
\hline Interval & Total Change & Annual Change \\
1973 to 1980 & 1.84 & 0.26 \\
1980 to 1986 & 1.37 & .23 \\
1986 to 1992 & 1.17 & .20 \\
1992 to 2000 & 1.75 & .22 \\
1973 to 2000 & 1.53 & .23 \\
\hline
\end{tabular}

conversions to agriculture came from mechanically disturbed ( 0.1 percent), wetland ( 0.03 percent), or mining reclamation ( 0.06 percent); (table 4$)$. The cumulative change in percent of regional area in the agriculture land class category averages to approximately 64.8 percent.

The second most significant sector of land-use change was agricultural land converted to developed land ( 0.32 percent). An increase of this conversion in the 1990s accounts for the rise of overall land-use change (table 2). The second greatest contributor to development was forest lands ( 0.06 percent), which maintained a steady rate until after 1992. Mechanically disturbed lands were converted to development throughout the study period ( 0.01 percent), despite a dramatic decrease in this change from 1980 to 1986 . Transitions from agricultural and forest lands to developed land were largely a one-way process; developed land did not lose ground during the study period.

The third most common type of land cover is not really land use, but an indicator of change. Mechanical disturbance on the land was observed most frequently from 1973 to 1980, though some types of mechanically disturbed land associated with agriculture ( 0.03 percent), forest ( 0.01 percent), and grass/shrub land ( 0.25 percent) was evident throughout the study period. The conversion of mechanically disturbed land to agriculture outpaced its conversion to developed land before 1980 and from 1992 to 2000, but from 1980 to 1986, the conversion of disturbed land transitioned to grass/shrub land instead. The conversion of forest to mechanically disturbed land (0.03 percent) occurred from 1973 to 1992, with the most active period from 1973 to 1980; this association declined again from 1992 to 2000. A rise in mining on agricultural land occurred from 1986 to 1992, and continued from 1992 to 2000 , but reclamation back to agriculture, water, or to grassland began after 1986 and continued through 2000.

Natural lands, land areas not managed for economic production, such as succession landscapes, glades, or wetlands, decreased in the 1980s, but experienced slight recoveries or maintained stability in the 1990s. Natural land cover change cycles, particularly vegetative succession from grass/ shrub land to forest (0.05 percent), initially were predominant, but the rate dropped in the late 1980s. Grass/shrub land also declined from 0.44 percent in the 1980's and stabilized at 0.45

Table 3. Gross change in regional area of the most common land-use conversions in the Interior Lowland ecoregion by percent, in intervals from 1973-2000.

\begin{tabular}{lcccc}
\hline & \multicolumn{3}{c}{ Change, in percent } \\
\cline { 2 - 4 } \multicolumn{1}{c}{ Land use Category } & $\mathbf{1 9 7 3 - 1 9 8 0}$ & $\mathbf{1 9 8 0 - 1 9 8 6}$ & $\mathbf{1 9 8 6 - 1 9 9 2}$ & $\mathbf{1 9 9 2 - 2 0 0 0}$ \\
\hline Water to wetland & 0.02 & 0.02 & 0.01 & .03 \\
Mechanically disturbed to developed & .04 & .01 & .01 & .01 \\
Mechanically disturbed to forest & .01 & No data & No data & No data \\
Mechanically disturbed to grass/shrub & No data & .02 & .01 & No data \\
Mechanically disturbed to agriculture & .05 & .03 & No data & .01 \\
Mining to agriculture & No data & No data & .05 & .15 \\
Forest to developed & .06 & .03 & .01 & No data \\
Forest to mechanically disturbed & .06 & .02 & .44 & .26 \\
Forest to agriculture & .92 & .65 & .02 & .05 \\
Grass/shrub to forest & .06 & .07 & .02 & .07 \\
Agriculture to water & .02 & .02 & .18 & .62 \\
Agriculture to developed & .33 & .15 & No data & .01 \\
Agriculture to mechanically disturbed & .01 & .01 & .15 & .02 \\
Agriculture to mining & .02 & .03 & .03 & .13 \\
Agriculture to forest & .06 & .04 & .04 & .03 \\
Agriculture to grass/shrub & .01 & .02 & .01 & .04 \\
Agriculture to wetland & No data & .05 & No data & .01 \\
Wetland to agriculture & .01 & .11 & \\
\hline
\end{tabular}




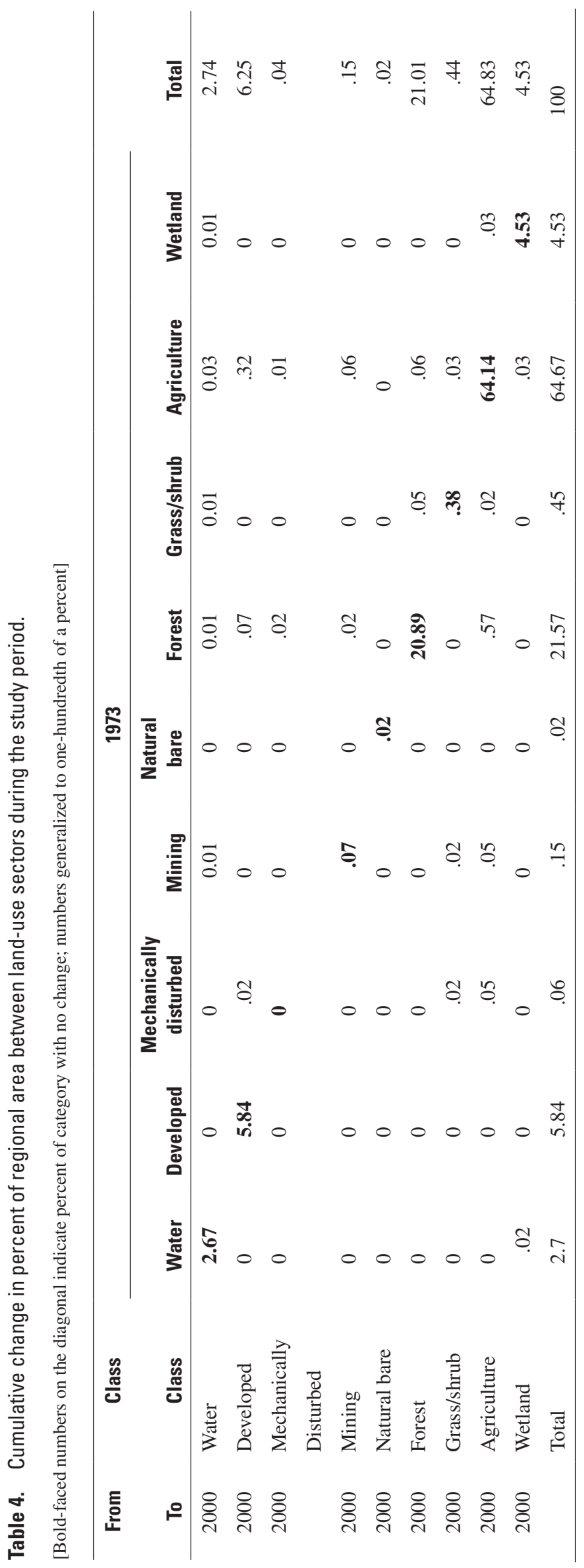

percent of total area from 1992 to 2000. Natural barren areas remained relatively stable, varying more than 0.02 percent of total regional area from 1973 to 2000 . Wetlands initially declined, but recovered to a total of 4.56 percent at the start and end of the study period while areas covered by water increased linearly, from 2.64 percent to 2.80 percent of the total area, from 1973 to 2000.

Net changes of land use categories are shown in table 5. The information cannot be presented as total area because measures were made from samples.

\section{Discussion}

\section{Comparative Findings at the Regional Scale}

This section focuses primarily on the land-use change analysis results compared to other research findings, and suggests future study of social, economic, or environmental implications of these results. Two other extensive and contemporary sources are used for the primary comparison to the earlier and later parts of this project (a gap of a few years falls between the two). Comparisons indicate differences in temporal and geographical extent, ecoregion categorization, land-use classification, methods, and the data models of sources. A summary of the comparative results appears in table 6. The discussion ends with the findings of two studies that used a representative watershed, a type of sampling approach, to draw conclusions about the region. These more detailed studies clarify some environmental aspects of land-use change.

A land-use land-cover change study published by the University of Illinois at Urbana-Champaign (UIUC) in 1979 (Schneider and Fettig, 1979) quantified acres of land and their conversion to other land-type categories from 1967 to 1975, and made projections for land-use conversions from 1975 to 1985 and 1985 to 1990 . The study was based on countylevel census data for the state of Illinois. The UIUC study delineated four agricultural production areas in Illinois by

Table 5. Net change by land-use category, 1973 to 2000.

\begin{tabular}{lc}
\hline \multicolumn{1}{c}{ Land use class category } & Change, in percent \\
\hline Developed & 1.61 \\
Agriculture & .66 \\
Water & .16 \\
Wetlands & .01 \\
Natural bare & 0 \\
Mining & -.02 \\
Grass/shrub land & -.06 \\
Mechanically disturbed & -.09 \\
Forest & -.27
\end{tabular}




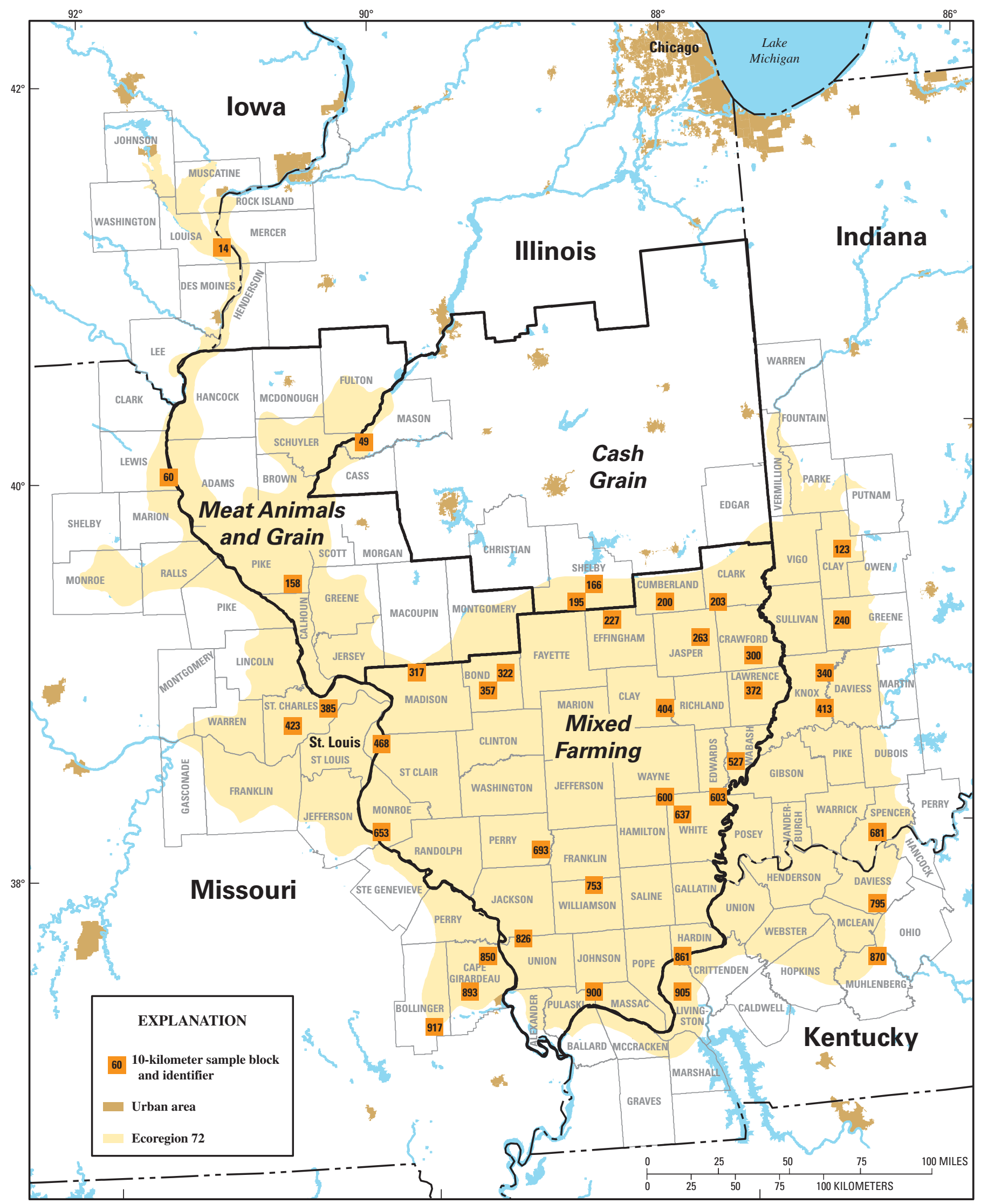

Environmental Systems Research Institute, Inc. (ESRI) Data and Maps, 2006

Figure 2. Ecoregion and University of Illinois at Urbana-Champaign agricultural area borders in Illinois. 
the majority of the farm production based on census numbers (fig. 2). Only 3 of the 4 areas intersect with the Interior River Lowland ecoregion and are thus shown in figure 2. The southern area had a combination of production such that no two product types made up a majority. This is an area that tended to have smaller operations, with off-farm employment that was an important source of income for agricultural operators. The second source used for a comparison of results is a U.S. Department of Agriculture(USDA) Forest Service study of land-use change for seven states in the upper Midwest from 1980 to 2000 (Potts and others, 2004). The GIS mapping from the USDA Forest Service investigation produced an area broader than the entire ecoregion, excluding about seven counties in northwestern Kentucky. A comparison of actual numbers of analysis is not possible because of differences in data, methods, and temporal and geographical extent. General trends are comparable to the USGS report because the UIUC and USDA Forest Service studies had similar objectives to the research described in this USGS report, and some correspondence exists in approaches. The comparison also is valid because southern Illinois is the consistent "core" of alternative delineations of the ecoregion (Cleland and others, 2005). The random sampling method of the USGS study assumes that actual percentage values derived from those samples represent the entire study area and environmental consistency and spatial coincidence or dependency for the entire ecoregion. Though the ecoregion extends beyond the Illinois state boundaries, the basis for a general comparison of selected parts of Illinois between these studies is that the largest part of the ecoregion area is in Illinois; the majority of sampling blocks ( 22 of 40) were within southern Illinois and 4 were in west-central Illinois. Of the four delineated areas of the UIUC study, the boundary of the southern area is almost exactly coincident with the ecoregion delineation (fig. 2). The remainder of the ecoregion within Illinois is within the boundaries of the UIUC western Illinois study area. The second comparison to be made between the USGS study and the USDA Forest Service study, is the similar problem of boundary delineation. However, the geographical extent of the USDA Forest Service study exceeds the ecoregion. The USGS and USDA Forest Service study are similar in that both data sets were based on remote sensing sources (Bergen and others, 2005), but the USDA Forest Service produced wall-to-wall GIS data rather than samples. Schneider and Fettig (1979) described the baseline conditions in the early 1970s; the primary trends in land-use conversion were from forest and grasslands, including pasture, to cropland and water. Differences were noted between farm and nonfarm woodland and grassland. Demand for non-agricultural and cropland depleted forests and grasslands. Though farm woodlands, grasslands, and non-farm grasslands all decreased, non-farm woodlands increased because of an effort on the part of the state government to meet the recreational demands of a growing population. Grassland and forest had high rates of conversion to cropland, but land-use conversions generally took several alternative options. Some converted directly from cropland to more intensive land use (development or water), or idled and converted first to grassland, then to forest, and later to intensive non-agricultural uses.

More high quality farmland converted to intensive non-farm uses because of the greater quantity of high quality farmland in Illinois than in the rest of the Corn/Grain Belt, and because good farmland also makes good land for development. Conversions to urbanization occurred mostly in ex-urban areas of large cities; thus, population levels and urban development were expected to remain proportionately the same in southern Illinois in the future. Mining is controlled by technological developments and economics of coal/oil. Trends in reclamation were affected by stronger regulations on new permits that went into effect in 1971. As of 1977, most reclaimed land went to pasture; however, more land eventually was converted to cropland than was cropland before strip mining. These trend findings were similar to USGS results (table 6).

The USDA Forest Service study results of larger landuse categories (developed, agriculture, and forestland) were similar to the USGS results (table 7). The land-use change percentages of smaller categories (mining, natural barren land, and water) were variable; changes in percent of small categories are more difficult to capture. Differences also are attributable to categorization inconsistencies.

In 1998, 94 percent of Illinois forest was timberland, quickly harvested, and having minimum ecologically productive capabilities (Schmidt and others, 1998, p. 1). The need for soil erosion control, made evident after the Dust Bowl of the Depression, the lobby for waterfowl hunting, and the conservation movement that arose in the 1960s and 1970s, drove efforts for the identification of ecologically beneficial land. Government-supported outdoor recreation facilities tend to center on the rivers. The primary recreational opportunities in the region are parks, wildlife refuges, lakes, and historical sites.

\section{Comparative Local Studies}

Local land-use studies focused on environmental specifics of land-use change, and present their findings to be representative of the larger region. One such research design focuses on the Cache River Basin of southern Illinois. These findings reflect the predominance of agricultural and forest land-use categories in land-use/land-cover change analysis (Iverson, 1988). Duram and others (2004), in their study of the Cache River watershed, detected a slight increase of the forest areas in the uplands from 1938 to 1993. Agriculture stabilized to approximately 50 percent of land-use/land-cover in the 20th century; decreasing in the upland and increasing in bottom lands. Increases were evident in grassland (including natural and agricultural) in all topographic zones. Swamps had declined from baseline levels by 1993 in topographic lowland; large lakes disappeared completely and were replaced by farm ponds as the predominant water bodies.

Generally, agricultural practices expanded in the lowland when the technology for draining natural wetlands developed. 
Table 6. Trends in St. Louis statistical metropolitan area total population change.

[SMA, Statistical Metropolitan Area; Mo, Missouri; Ill, Illinois; Source: U.S. Bureau of the Census, 1960, 1990, and 2000]

\begin{tabular}{lrrrrrr}
\hline \multicolumn{1}{c}{ Counties } & $\mathbf{1 9 6 0}$ & \multicolumn{1}{c}{$\mathbf{1 9 9 0}$} & Net change & $\begin{array}{r}\text { Percent } \\
\text { change }\end{array}$ & \multicolumn{1}{c}{$\mathbf{2 0 0 0}$} & Added to SMA \\
\hline St. Louis, Mo. & $703,532.0$ & $993,508.0$ & $289,976.0$ & 41.2 & $1,016,315.0$ & pre-1960 \\
St. Charles, Mo. & $52,970.0$ & $212,752.0$ & $159,781.0$ & 301.6 & $283,883.0$ & pre-1960 \\
St. Clair, Ill. & $262,509.0$ & $262,852.0$ & 343.0 & .1 & $256,082.0$ & pre-1960 \\
Madison, Ill. & $224,689.0$ & $249,238.0$ & $24,549.0$ & 10.9 & $258,941.0$ & pre-1960 \\
Jefferson, Mo. & $66,377.0$ & $171,380.0$ & $105,003.0$ & 158.2 & $198,099.0$ & 1960 \\
Franklin, Mo. & $44,566.0$ & $80,603.0$ & $36,037.0$ & 80.9 & $93,807.0$ & 1970 \\
Clinton, Ill. & $24,029.0$ & $33,944.0$ & $9,915.0$ & 41.3 & $35,535.0$ & 1980 \\
Monroe, Ill. & $15,507.0$ & $22,422.0$ & $6,915.0$ & 44.6 & $27,619.0$ & 1980 \\
Jersey, Ill. & $17,023.0$ & $20,539.0$ & $3,516.0$ & 20.7 & $21,668.0$ & 1990 \\
Calhoun, Ill. & $5,933.0$ & $5,322.0$ & -611.0 & -10.3 & $5,084.0$ & 1990 \\
Warren, Mo. & $8,750.0$ & $19,534.0$ & $10,784.0$ & 123.2 & $24,525.0$ & 2000 \\
Lincoln, Mo. & $14,783.0$ & $28,892.0$ & $14,109.0$ & 95.4 & $38,944.0$ & 2000 \\
Total & $1,440,668.0$ & $2,100,986.0$ & $660,318.0$ & 45.8 & $2,260,502.0$ & \\
City of St. Louis & $750,026.0$ & $396,685.0$ & $-353,341.0$ & -47.1 & $348,189.0$ & \\
\hline
\end{tabular}

Table 7. Land-use change trends findings from comparative studies by land-use categories.

[USGS, U.S. Geological Survey; UIUC, University of Illinois at Urbana-Champaign; USDA Forest Service, U. S. Department of Agriculture Forest Service]

\begin{tabular}{llll}
\hline \multicolumn{1}{c}{ Land-use class } & \multicolumn{1}{c}{$\begin{array}{c}\text { USGS } \\
(\mathbf{1 9 7 3 - 2 0 0 0 )}\end{array}$} & \multicolumn{1}{c}{$\begin{array}{c}\text { UIUC } \\
(\mathbf{1 9 6 7 - 1 9 7 5 )}\end{array}$} & \multicolumn{1}{c}{$\begin{array}{c}\text { USDA Forest Service } \\
(\mathbf{1 9 8 0}-\mathbf{2 0 0 0})\end{array}$} \\
\hline $\begin{array}{lll}\text { Agriculture } \\
\text { Developed }\end{array}$ & $\begin{array}{l}\text { Forest to agriculture } \\
\text { Increased }\end{array}$ & $\begin{array}{l}\text { Crop intensification } \\
\text { Growth in ex-urban periphery; } \\
\text { decrease in population density }\end{array}$ & $\begin{array}{l}\text { Increased slightly } \\
\text { Increased }\end{array}$ \\
Mining & High-low-stabilized & Category not used & Category not used \\
Forestland & Increased then fell & Increase of reclamation & Increased \\
Grass/shrub land & Declined & Declined & Declined \\
Wetland & Fell, then stablized & Declined & Data grouped with agriculture \\
Water & Fell, then recovered & Category not used & Unchanged \\
\hline
\end{tabular}

Farm field consolidation for larger, industrial farming also accounts for the conversion of smaller plots to agriculture in some areas. The agricultural economy is stabilized by price subsidies by the Federal government, which may reward the conversion of land to agriculture. The Federal government also provides financial incentives to remove land from production, which may raise the price of commodities. The Clean Water Act (Federal Water Pollution Control Acts, 1972) slowed the conversion of remaining wetlands to farming. The withdrawal of lands from farming was supported by conservation programs that initially moved marginal lands from farm produc- tion and into forestland via the U.S. Department of Agriculture Conservation Reserve Program of 1985, and later allowed farms in drainage areas to convert to wetlands supported by the U.S. Department of Agriculture Wetland Reserve Program. Transitions from water to wetland may have been the result of periodicity in wetlands or restoration efforts. Though these studies analyzed the history of one watershed, the intent was to make the study representative of the region, and to provide an in-depth view of the components of land-use change.

Another example of local land-use change, particularly of a single sector, is the city of St. Louis. Manufacturing has 
significantly declined because of foreign competition, liability and health insurance costs, tariffs and taxes, and equipment depreciation recovery and reinvestment costs (U.S. Congress, 2003). The city of St. Louis is still a leading producer for the aerospace and defense industries, but losses in manufacturing are symptomatic of a declining middle-class demographic group. St. Louis has been removed from the list of the ten largest cities in the United States since the beginning of the study period (Hobbs and Stoops, 2002, p. 37). The city lost more than one-half of its population in the second one-half of the 20th century, declining from about 857,000 in 1950 to 396,685 in 1990 (Hobbs and Stoops, 2002, p. A6) and the decrease continued in the 1990s (table 8). Population has increased dramatically in the suburbs and greater metropolitan statistical area, however. The population of the metropolitan area within this ecoregion has more than doubled since 1950, reaching an estimated 2,547,686 in 1995. Land use generally is attributed to local decisions made by people and institutions in response to changing economic, political, and cultural factors operating at broader geographical extents. The immediate humanenvironmental conditions direct these response decisions into specific environmental changes (Lambin and others, 2001). In the Interior River Lowland ecoregion, crop farming has intensified faster than urbanization, and at the cost of low-intensity land uses for ecosystem services and recreation. These trends generally are reflected in other studies of the region. Although the results vary on the subject of forestlands, the sampling approach using remote sensing sources appears effective in capturing information consistent with methods based on census enumerations or GIS mapping.

\section{Conclusions}

The analytical approaches used for this study resulted in a picture of the Interior River Lowland ecoregion as a rich natural environment with a low to moderate demand for competing land uses, despite relatively low population, that maintains the stability and growth of the region. Although the environmental conditions that persisted at the time of European contact in the region were modified by deforestation, agriculture, and to a smaller degree by mining, increased potential for agriculture, mining, water systems, and cultural and natural conservation/ recreation will likely continue in the future. Urbanization is based on mixed and diverse economies, and its future direction may vary because of corresponding changes occurring at broader geographical scales.

The U.S. Geological Survey method for quantifying and analyzing land-use changes, based on sampling, in the Interior River Lowland ecoregion produced similar results as other techniques based on census and GIS surveys (table 6). The relative stability of the land use of the ecoregion, however, may account for cohesive analysis results.

\section{References Cited}

Bergen, K.M., Brown, D.G., Rutherford, J.F., and Gustafson, E.J., 2005, Change detection with heterogeneous data using ecoregional stratification, statistical summaries and a land allocation algorithm: Remote Sensing of the Environment, v. 97 , p. 434-446.

Changnon, S.A., Angel, J.R., Kunkel, K.E., and Lehmann, C.M.B., 2004, Climate atlas of Illinois: Illinois State Water Survey, Champaign, Ill., 309 p.

Table 8 Change in land-use categories by percent between comparative studies, 1980 to 2000.

[USGS, United States Geological Survey; USDA Forest Service, United States Department of Agriculture Forest Service]

\begin{tabular}{lclc}
\hline \multicolumn{1}{c}{ Land Use Category } & Percent & \multicolumn{1}{c}{$\begin{array}{c}\text { USDA } \\
\text { Land Use Category }\end{array}$} & Percent \\
\hline Agriculture & 0 & Agriculture & 2 \\
Grass/shrub land, including pasture & 2 & Grouped with agriculture & No data \\
Developed, including Transportation & 18 & Urban & 20 \\
Mechanically Disturbed & 95 & Category not used & No data \\
Mining & -10 & Barren, including Mining & 17 \\
Natural Bare & 100 & Grouped with Barren & No data \\
Forest & -6 & Forest & -11 \\
Wetlands & 2 & Wetlands & 0 \\
Water & -5 & Water & -1 \\
\hline
\end{tabular}


Christensen, D.E., and Harper, R.A., eds., 1967, The Mississippi-Ohio confluence area, A geographic interpretation of the Belleville 1:250,000 Topographic Map. Geography Through Maps Series, Special Publication Number 12, National Council for Geographic Education, Illinois State University, Normal, Ill., 49 p.

Cleland, D.T., Freeouf, J.A., Keys, J.E., Nowacki, G.J., Carpenter, C., and McNab, W.H., 2005, Ecological subregions: sections and subsections of the conterminous United States (map on cd-rom) (A.M. Sloan, cartographer). Washington, D.C.: U.S. Department of Agriculture Forest Serivce, presentation scale 1:3,500,000; colored. Also available on CD-ROM consisting of GIS coverages.

Duram, L.A., Bathgate, J., and Ray, C., 2004, A local example of land-use change: Southern Illinois-1807, 1938, and 1993: The Professional Geographer, v. 56, no. 1, p. 127140.

Federal Water Pollution Control Act Amendments of 1972, Pub. L. 92-500, Oct. 18, 1972, 86 Stat. 816.

Fenneman, N.M., 1946, Physical divisions of the United States, U.S. Geological Survey physiographic map, scale $1: 7,000,000$.

Griffith, J.A., Stehman, S.V., Sohl, T.L., and Loveland, T.R., 2003, Detecting trends in landscape pattern metrics over a 20-year period using a sampling-based monitoring programme: International Journal of Remote Sensing, v. 24, no. 1, p. 175-181.

Hobbs, F., and Stoops, N., 2002, Demographic Trends in the 20th Century, U.S. Census Bureau, Census 2000 Special Reports, Series CENSR-4: Washington D.C., U.S. Government Printing Office, 163 p., accessed October 25, 2006, at URL http://www.census.gov/prod/2002pubs/censr-4.pdf.

Iverson, L.R., 1988, Land-use changes in Illinois, USA: The influence of landscape attributes on current and historic land use: Landscape Ecology, v. 2, no. 1, 45 p.

Jacobson, R.J., and Korose, C., 2003, Coal geology of Illinois: 2003 Keystone Coal Industry Manual, Denver, Colorado, Mining Media, p. 512-514, accessed October 25, 2006, at URL http://www.isgs.uiuc.edu/coalsec/Illinois-coalgeology. $p d f$.

Kircher, H.B., 1967, The Southern Illinois Prairies, A geographic interpretation of the Belleville 1:250,000 Topographic Map: Geography Through Maps Series, Special Publication Number 11, National Council for Geographic Education, Illinois State University, Normal, Illinois, 39 p.
Lambin, E.F., Turner, B.L., II, Geist, H.J., Agbola, S.B., Angelsen, A., Bruce, J.W., Coomes, O., Dirzo, R., Fischer, G., Folke, C., George, P.S., Homewood, K., Imbernon, J., Leemans, R., Li X., Moran, E.F., Mortimore, M., Ramakrishnan, P.S., Richards, J.F., Skånes, H., Steffen, W.L., Stone, G.D., Svedin, U., Veldkamp, T.A., Vogel, C., $\mathrm{Xu}, \mathrm{J} ., 2$ 2001, The causes of land-use and land-cover change: Moving beyond the myths: Global Environmental Change, v. 11, p. 261-269.

Lant, C., Loftus, T., Kraft, S., and Bennett, D., 2001, Land-use dynamics in a Southern Illinois (USA) Watershed: Environmental Management, v. 28, n. 3, p. 325-340.

Loveland, T.R., Sohl, T.L., Stehman, S.V., Gallant A.L., Sayler, K.L., and Napton, D.E., 2002, A strategy for estimating the rates of recent United States land-cover changes: Photogrammetric Engineering and Remote Sensing, v. 68, p. 1,091-1,099.

Omernik, J.M., 1987, Map Supplement: Ecoregions of the conterminous United States: Annals of the Association of American Geographers, v. 77, no. 1, p. 118-125.

Omernik, J.M., 1995, Ecoregions: A spatial framework for environmental management, Biological Assessment and Criteria: Tools for Water Resource Planning and Decision Making, Davis, W.S. and Simon T.P. (eds.) Lewis Publishers, Boca Raton, Florida. p. 49-62.

Omernik, J.M., 2006, U.S. Level III Descriptions, accessed October 25, 2006, at URL http://www.epa.gov/wed/pages/ ecoregions/level_iii.htm.

Potts, R., Gustafson, E., Stewart, S.I., Thompson, F.R., Bergen, K., Brown, D.G., Hammer, R., Radeloff, V., Bengston, D., Sauer, J., and Sturtevant, B., 2004, The changing midwest sssessment: land cover, natural resources, and people: General Technical Report NC-250, St. Paul, Mn.: U.S. Department of Agriculture, Forest Service, North Central Research Station, 87 p.

Riitters, K.H., Wickham, J.D., and Wade, T.G., 2006, Evaluating ecoregions for sampling and mapping land-cover patterns: Photogrammetric Engineering \& Remote Sensing, v. 72, n. 7, p. 781-788.

Schmidt, T.L., Hansen, M.H., and Solomakos, J.A., 2000, Illinois' Forests in 1998: Resource Bulletin NC-198. St. Paul, Mn.: U.S. Department of Agriculture Forest Service, North Central Forest Experiment Station, 133 p.

Schneider, R.E., and Fettig, L.P., 1979, Changes in the farmland base: Urbana, Ill., University of Illinois at UrbanaChampaign, 39 p.

St. Louis City Plan Commission, 1969, Physical growth of the city of St. Louis, accessed October 25, 2006, at URL http:// stlouis.missouri.org/heritage/History69/index.html\#20th. 
Stehman, S.V., Sohl, T.L., and Loveland, T.R., 2003, Statistical sampling to characterize recent United States land-cover change: Remote Sensing of Environment, v. 86, issue 4, p. 517-529.

U. S. Congress, House Committee on Small Business, Subcommittee on Workforce, Empowerment, and Government Programs, 2003, Status of small business manufacturing in the Midwest: Hearing before the Subcommittee on Workforce, Empowerment \& [sic] Government Programs of the Committee on Small Business, House of Representatives, One Hundred Eighth Congress, first session, Washington, D.C., April 28, 2003: Washington, U.S. Government Printing Office.

U.S. Geological Survey Land cover trends, accessed July 16, 2007, at URL http://edc2.usgs.gov/LT/index.php.

Prepared by:

USGS Enterprise Publishing Network

Rolla Publishing Service Center

1400 Independence Road

Rolla, M0 65401

For more information concerning this publication, contact:

Director

U.S. Geological Survey

Mid-Continent Geographic Science Center

1400 Independence Road

Rolla, M0 65401

(573) 308-3679

Or visit the Mid-Continent Geographic Science Center website at: http://mcmcweb.er.usgs.gov/mcgsc/ 



\section{苑}

1

올

$\exists$

कำ

吾

इ

$\stackrel{\pi}{\circ}$

高:

高

.

䓂.

D

뀽

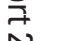

产

总

Printed on recycled paper 